Special Issue (October)

\title{
FORMULATION OF TABLET FROM PAPAYA AND BAY LEAF EXTRACT WITH VARIATION OF CONCENTRATION POLYVINYLPYRROLIDONE AS A BINDER
}

\author{
ERNI RUSTIANI*, MIRA MIRANTI, NURUL KARIMA RAHMAHUDA \\ Department of Pharmacy, Pakuan University, Bogor, Indonesia. Email: e_rustiani@yahoo.com
}

Received: 21 April 2017, Revised and Accepted: 13 July 2017

\begin{abstract}
Objectives: Extensive studies on the pharmacological activities of papaya and bay leaf exhibit that these plants effectively alleviate degenerative diseases including diabetes. However, herbal drugs from papaya and bay leaf have never been made. The aim of this research was to formulate a tablet from the combination of papaya extract and bay leaf with different concentrations (1\%, 2\%, and 3\%) of polyvinylpyrrolidone (PVP) K30 as a binder using the wet granulation method.
\end{abstract}

Methods: Evaluation of the tablet's physical properties (i.e., weight variation, friability, hardness, disintegration time, and physical appearance) was done using standard methods while total flavonoid in the extracts was determined by the spectrophotometry method.

Results: The tablet was light brown and had both flat top and bottom, a specific odor and a bitter taste. The physical properties of the tablet were in accordance with pharmaceutical standards. The total flavonoid content in the papaya and bay leaves extract was $1.562 \%$ and $2.240 \%$, respectively.

Conclusions: It can be concluded that PVP K-30 concentration can be used as a binder to formulate dry papaya and bay leaf extracts into high-quality and ready-to-consume tablets.

Keywords: Papaya leaf extract, Bay leaf extract, Tablets, Polyvinylpyrrolidone K30, Flavonoid.

(C) 2017 The Authors. Published by Innovare Academic Sciences Pvt Ltd. This is an open access article under the CCBY license (http://creativecommons. org/licenses/by/4. 0/) DOI: http://dx.doi.org/10.22159/ajpcr.2017.v10s5.23124

\section{INTRODUCTION}

Papaya fruit is a rich source of phytonutrients, minerals, vitamins, and other compounds such as alkaloids, saponins, tannins, and flavonoids, which have antioxidant activity and potential as an antihyperglycemic agent. A previous study revealed that $5 \mathrm{mg} / \mathrm{kg} \mathrm{BW}$ papaya extract can significantly reduce blood glucose level in experimental mice [1]. Bay leaves, in addition to their use as a food seasoning, have traditionally been used to treat gout, high cholesterol, and diabetic diseases. The active compounds found in bay leaf such as eugenol, tannins, and flavonoids are responsible for the plant's medicinal properties [2]. Bay leaf extract at a dose of $1.36 \mathrm{mg} / \mathrm{kg}$ showed strong antihyperglycemic activity in experimental mice [3].

Flavonoids are found abundantly in papaya and bay leaf, and these groups of compounds play an important role in the pharmacological properties of these plants. Both papaya and bay leaf extracts contain flavonoids, and the combination of these two extracts is expected to have an optimum effect as an antihyperglycemic medicine. In this study, two extracts were combined and formulated into a tablet. The tablet form was selected to formulate papaya and bay leaf extracts into a useful drug because the tablet form has many advantages compared to other forms of drug such as uniform size, ease of consumption durability, and ease of storage.

The binder or adhesive substance is needed to make good tablet, compact, and strong [4,5]. One binder commonly used for making tablets is polyvinylpyrrolidone (PVP), as PVP has not shown any toxic effect and is easily absorbed from the gastrointestinal tract or mucous membranes when taken orally. The concentration of PVP used as a binder ranges between $0.5-5 \%$ [6]. The granules that use PVP as a binder have good flow properties, have a minimum angle of repose, have better compressibility and produce fewer fines [7].

The formulation of a papaya extract tablet using 1\% PVP K-30 as a binder yields eligible tablets and a better texture is obtained with the addition of super disintegrant Ac-Di-Sol to the formula to accelerate tablet disintegration time. Thus, the aim of this study was to formulate a tablet from the combination of papaya and bay leaf extracts using the Ac-Di-Sol as a super disintegrant. The concentration of Ac-Di-Sol used in the wet crusher materials granulation process is $3 \%$ [6]. To obtain the best tablet formula, papaya leaf and bay leaf extracts were combined and different concentrations of PVP K-30 (1\%, 2\%, and $3 \%$ ) were added. The quality of the resulting tablet was determined by an organoleptic test, which assesses weight uniformity, size uniformity, hardness, friability, disintegration time, and dissolution time.

\section{METHODS}

Tools and materials

The tools used were digital scales (AND G-120), an oven, a funnel, calipers, a Tap Density meter (USP Bulk Density Tester 315-2E), a Flow meter, stopwatches, a tablet printer (Delta), a friability test (Panjaya Teknik), a hardness tester (Schleuniger-2E), a desiccator, a disintegration tester (Vanguard Pharmaceutical Machinery Inc., USA), moisture balance (AND MX 50), a furnace (Ney), a spectrophotometer ultraviolet-visible (UV-Vis) (Optizen), a Vacuum Dryer (Ogawa), and glass tools.

The materials used were PVP K-30, Avicel pH 102, Ac-Di-Sol, Talc and magnesium stearate, $96 \%$ ethanol, distilled water, hydrochloric acid $2 \mathrm{~N}$, gelatin $1 \%$, sodium chloride $10 \%$, iron (III) chloride, hydrochloric acid, sodium acetate $1 \mathrm{M}$, methanol, magnesium powder, reagent Mayer, Bouchardat, Dragendorff, quercetin, and aluminum chloride 10\%. All chemicals used were of analytical grade.

Papaya leaves were collected from Mekarsari Garden, and bay leaves were collected from Cijeruk area. Both collection sites are located in Bogor Residence, West Java, Indonesia. The leaves' ware was determined in the Center for Plant Conservation, Indonesian 
Institute of Sciences, Bogor Botanical Gardens. Papaya and bay leaves were cleaned and washed under running water and then dried in an oven at a temperature of $60^{\circ} \mathrm{C}$. The leaves were then grinded and sieved through a 40-mesh sieve to obtain powder for further study.

\section{Characterization of plant materials}

Determination of water content

The water content of the plant materials was calculated according to the standard method using moisture balance apparatus.

\section{Determination of ash content}

Ash content was determined after the plant materials were ashed in the furnace at a temperature of $600^{\circ} \mathrm{C}[8]$.

\section{Extraction of papaya and bay leaves}

The extracts of papaya and bay leaves were prepared by the infusion method. $1200 \mathrm{~g}$ of papaya leaf powder were immersed in a pot that contained $6000 \mathrm{ml}$ of distilled water. $1000 \mathrm{~g}$ of bay leaf powder were immersed in a pot that contained $4000 \mathrm{ml}$ of distilled water. Each pot was then heated and occasionally stirred for 15 minutes. The temperature was gradually increased from $15^{\circ} \mathrm{C}$ to $900^{\circ} \mathrm{C}$. The liquid extract obtained was sieved and dried in a vacuum dryer to obtain concentrated papaya and bay leaf extracts.

\section{Phytochemical test}

\section{Flavonoid test}

The presence of flavonoids was detected using staining methods. The difference in the appearing color (marked in red, orange, or green) shows the variation of flavonoids in the sample.

\section{Alkaloid test}

The presence of flavonoids was detected using reagent Bouchardat LP. If the second trial does not precipitate, the powder does not contain alkaloids. If the LP Mayer reagent precipitates a white or yellow clot dissolved in methanol, and reagents Bouchardat LP precipitates a brown to black, then there will likely be an alkaloid [9]

\section{Saponin test}

The presence of saponin is characterized by the formation of foam in an aqueous solution with a height of $1-10 \mathrm{~cm}$, which is stable for no $<10$ minutes when a drop of hydrochloric acid $2 \mathrm{~N}$ was added to the solution [9].

\section{Tanin test}

The presence of tanin was determined according to a previous method:

a. The addition of $10 \%$ gelatin solution produces white precipitate. $\mathrm{NaCl}$-gelatin solution made from $1 \%$ gelatin solution in $10 \% \mathrm{NaCl}$ ratio of $1: 1$

b. The addition of $3 \%$ solution iron (III) chlorides produces green-bluish to black [10].

\section{Determination of total flavonoids extract}

\section{Determination of wavelength maximum quercetin}

A total of $10 \mathrm{ml}$ of a standard solution of quercetin in a methanol concentration of $10 \mathrm{ppm}$ was put in a $50 \mathrm{ml}$ flask. The solution added by $1 \mathrm{ml}$ of $\mathrm{AlCl}_{3} 10 \%, 1 \mathrm{ml}$ of $1 \mathrm{M}$ sodium acetate and distilled water to the limit of flask. The solution was shaken until it was homogeneous and was left to stand for 30 minutes. The absorbance at a wavelength of 380-780 $\mathrm{nm}$ was measured using a spectrophotometer.

\section{Determination of optimum incubation time}

The solution was measured at the maximum wavelength at 5, 10, 15, 20, 25 , and 30 minutes to determine the optimum time.

\section{Calibration curve of standard}

Quercetin standard solution series were made 2, 4, 6, 8, and $10 \mathrm{ppm}$. Standard solution $100 \mathrm{ppm}$ was pipetted $1,2,3$, 4, and $5 \mathrm{ml}$ into a $50-\mathrm{ml}$ flask. Then, $1 \mathrm{ml}$ of $\mathrm{AlCl}_{3} 10 \%$ and $1 \mathrm{ml}$ of $1 \mathrm{M}$ sodium acetate were added and diluted with distilled water to the limit of flask. The solution was shaken until it was homogeneous, and then, allowed at the optimum incubation time. The solution was then measured at a wavelength of maximum absorbance. Curve was made between the absorbance measurements and quercetin standard solution concentration. It was produced linear regression equation $(\mathrm{y}=\mathrm{bx}+\mathrm{a})$. The regression equation was used to calculate the extract concentration (ppm) by entering the extract absorbance as y-values into the equation.

\section{Determination of total flavonoids extract}

$200 \mathrm{mg}$ of papaya leaf extract, $54.4 \mathrm{mg}$ of bay leaf extract, and $254.4 \mathrm{mg}$ of a mixture of papaya leaf extract and bay leaves corresponded to 5 times the dose of each formula. Each performed the assay extract manner diluted with methanol to $50 \mathrm{ml}$ and was shaken for 10 minutes to extract soluble in methanol. Each solution of papaya extract, bay leaf extract, and the mixture of papaya and bay leaf extracts were pipetted into a 50 -ml flask. Then, $1 \mathrm{ml}$ of $\mathrm{AlCl}_{3} 10 \%$ and $1 \mathrm{ml}$ of $1 \mathrm{M} \mathrm{Na}$ acetate was added. Distilled water was added to the limit of flask. The solution was shaken until it was homogeneous and then allowed at the optimum incubation time. Absorption was then measured at the maximum wavelength the resulting absorbance was added to the regression equation of the standard curve quercetin, and the total flavonoid content was then calculated.

\section{Tableting methods}

Three different formulas were used to make a tablet, as shown in Table 1. Each formula consisted of 500 tablets, and each tablet weighed $300 \mathrm{mg}$.

A tablet was made using the wet granulation method. All ingredients were sieved using 30 meshes. Papaya leaf extract, bay leaf extract, PVP-K30, Ac-Di-Sol, and Avicel pH 102 were weighted according to the formula. PVP K-30 as a binder solution was prepared by dissolving it in $70 \%$ ethanol. All the ingredients were stirred to obtain a homogenous mixture. The binder was stirred into the mixture to enhance the strength of the powder particles. Wettable powders were formed into granules or a moist mass to make a granulation. Moist granules or powder-sieved wet mass was pressed past an 8-mesh sieve to make granules. The granules were dried in an oven that was thermostatically controlled to record a time, temperature, and humidity constant.

\section{Determination of flavonoid content in the tablet}

The total flavonoid content in the tablet was determined using a method similar to that used to determine the total flavonoid content in papaya and bay leaf extracts. 20 tablets were weighed and then crushed into a fine powder. The powder weighed equivalent to the content of the amount of extract $254.4 \mathrm{mg}$. A total number of grams of the powdered tablets that had been equated were put in a $50-\mathrm{ml}$ flask along with methanol to the limit. The solution was shaken for 20 minutes using a magnetic stirrer. Then, $2 \mathrm{ml}$ solution was pipetted, $1 \mathrm{~mL}$ of $\mathrm{AlCl}_{3} 10 \%$, and $1 \mathrm{ml}$ of sodium acetate $1 \mathrm{M}$ were added. Distilled water was added

Table 1: Tablet formulation from papaya and bay leaf extracts

\begin{tabular}{llll}
\hline \multirow{2}{*}{ Materials } & \multicolumn{2}{l}{ Formulation (\%) } \\
\cline { 2 - 4 } & I & II & III \\
\hline Papaya leaf extract & 13.35 & 13.35 & 13.35 \\
Bay leaf extract & 3.6 & 3.6 & 3.6 \\
PVP K-30 & 1 & 2 & 3 \\
Ac-Di-Sol & 3 & 3 & 3 \\
Mg stearate & 1 & 1 & 1 \\
Ac-Di-Sol & 0.5 & 0.5 & 0.5 \\
Talk & 2 & 2 & 2 \\
Avicel pH 102 ad. & 100 & 100 & 100 \\
\hline PVP: Polyvinylpyrrolidone & & &
\end{tabular}


up to the limit of the 50 -ml flask. The solution was shaken until it was homogeneous and then allowed for the optimum time. Absorption was then measured at the maximum wavelength. The resulting absorbance was inserted into the regression equation of the standard curve of quercetin.

\section{RESULTS AND DISCUSSION}

\section{Characterization of simplicial}

Fresh leaves of papaya and bay plants (Figs. 1 and 2) obtained 9.43\% of dry leaf powder. The papaya dry leaf powder has a bright green, a specific odor, and a very bitter taste with $4.84 \%$ of water content and $8.7 \%$ of ash content. The bay leaf powder shows a dark green, a specific aromatic odor, and a rather chelate and tart taste. The water and ash content of the bay powders were $4.78 \%$ and $4.7 \%$, respectively.

The dry extracts of papaya and bay leaves showed slight differences compared to their powder forms, as shown in Figs. 3 and 4. The water content of papaya and bay leaf dry extracts were $4.7 \%$ and $4.46 \%$, respectively; the ash content of papaya and bay leaf dry extracts were $9.4 \%$ and $8.2 \%$, respectively. The results obtained were in line with the recommended quality standard in which the ash content of bay leaf extract should not be more than $10.1 \%$ [11]. The value and quality of extracts varied depending on the extract's ash content, purity, and contaminants.

\section{Phytochemical test}

The results of phytochemical tests conducted on some classes of the main active compounds contained in the dry extracts of papaya and

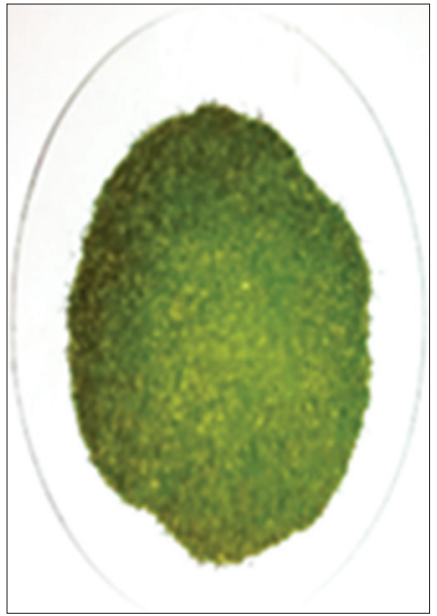

Fig. 1: Papaya leaf

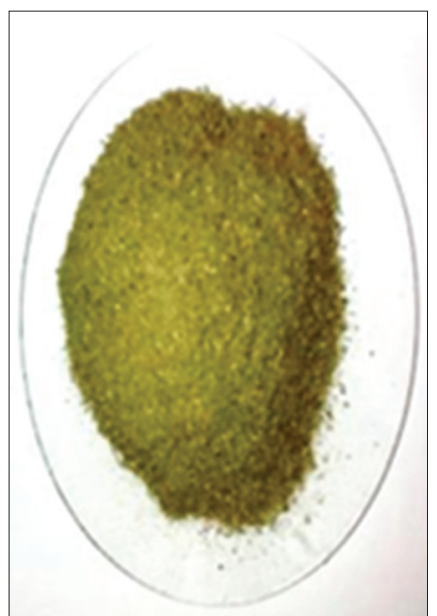

Fig. 2: Bay leaf bay leaves showed that both extracts contained flavonoids, alkaloids, saponins, and tannins in moderate-to-high levels.

\section{Total content of flavonoids}

The maximum absorption was $430 \mathrm{~nm}$. The optimum incubation time was 20 and 25 minutes with absorption of $0.151 \mathrm{~nm}$. The results of the linearity of the equation $y=0.0773 x-0.003$ with a correlation coefficient of $r=0.9998$, which confirms the linearity of the relationship between absorbance and concentration.

The total flavonoid content in the dry papaya and bay leaf extracts was $1.562 \%$ while the total flavonoid content of the mixture of papaya and bay leaf extract was $4.675 \%$. This data showed that the total flavonoid content of the mixture of dry papaya and bay leaf extracts were higher than level of total flavonoid content from those single extracts. Based on this data, papaya and bay leaf extracts were mixed to obtain higher levels of flavonoid content.

\section{Evaluation of granule characteristics}

The characteristics of the granules of dry papaya and bay leaf extracts were determined by measuring the water content, flow rate, friability, and compressibility of the granules, as shown in Table 2.

\section{Evaluation of tablet characteristics}

The uniformity in the weight of the papaya and bay leaf tablets was tested by weighing each tablet, and the results were presented as percentages of deviation. The results showed that the uniformity in the weight of the papaya and bay leaves tablets met the quality requirement

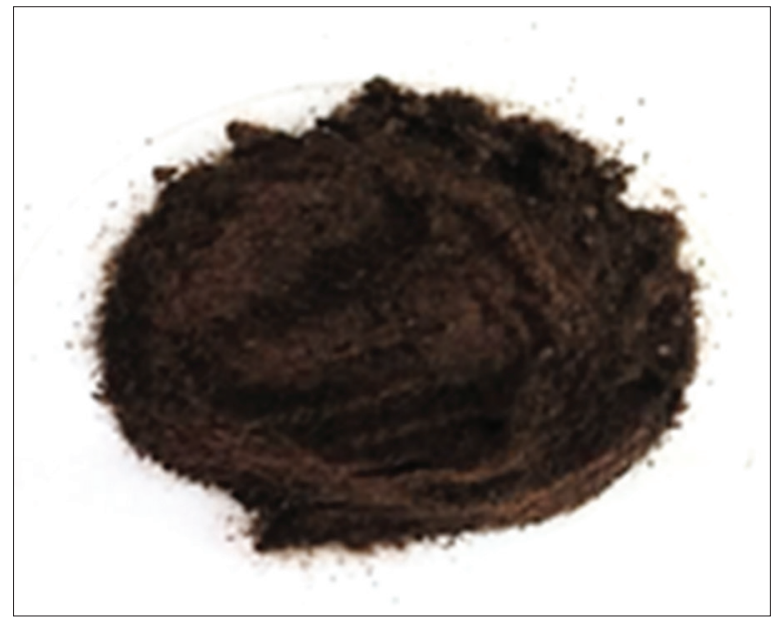

Fig. 3: Dry extract of papaya leaf

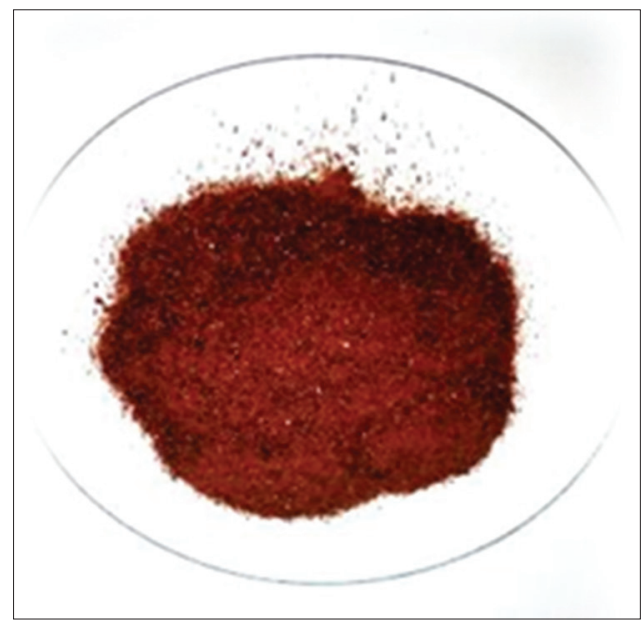

Fig. 4: Dry extract of bay leaf 
in which the deviation value tablets ranged from $5 \%$ to $10 \%$ for the tablets that weighed $300 \mathrm{mg}$ or more [12]. The thickness and diameter of the tablets can be seen in Table 3 and Fig. 5 . All formulas meet the requirement. Diameter of the tablets was not $>3$ times their thickness and not smaller than $1 \frac{1}{3}$ times their thickness [12].

The hardness of the tablets that resulted from the third formula is comparable to that of the tablets that resulted from the first and second formulas according to literature and as shown in Table 4, where the hardness of tablets range between 4 and $8 \mathrm{kp}$ [13]. The tablets that resulted from Formula II had the highest hardness compared to the tablets that resulted from Formula I and Formula III. This result could be associated with the high pressure used in the printing process of the tablets yields a high hardness level.

The results of a friability test (Table 5) show that all of the tablet formulas were eligible according to literature, as the average friability ranged between $0.8 \%$ and $1 \%$ [14]. The highest friability was found in the tablets with Formula III while the lowest friability was found in the tablets with Formula II. The discrepancy in the friability of the tablets may be related to the difference in the moisture content of Formulas I, II, and III.

The disintegration time of the tablets, as shown in Table 6, indicated that all tablet formulas were eligible according to the standard of

Table 2: Characteristics of the granules from dry papaya and bay leaf extracts

\begin{tabular}{llll}
\hline Granule evaluation & \multicolumn{2}{l}{ Formula } & \\
\cline { 2 - 4 } & I & II & III \\
\hline Water content (\%) & 3.30 & 3.53 & 4.16 \\
Flow test (g/s) & 12.16 & 11.06 & 10.80 \\
Angle of repose ( $\left.{ }^{\circ}\right)$ & 28.24 & 22.11 & 26.00 \\
Compressibility (\%) & 11.76 & 13.32 & 13.47 \\
\hline
\end{tabular}

Table 3: The thickness and diameter of the tablets

\begin{tabular}{llllll}
\hline Results & \multicolumn{2}{l}{$\begin{array}{l}\text { Average } \\
\text { measurement }\end{array}$} & & \multicolumn{2}{l}{ Requirement } \\
\cline { 2 - 3 } \cline { 5 - 6 } \cline { 5 - 6 } & Thickness & Diameter & & $\mathbf{1 1 / 3}$ & $\mathbf{3}$ \\
\hline Formula I & 0.393 & 0.957 & & 0.524 & 1.179 \\
Formula II & 0.392 & 0.957 & & 0.523 & 1.176 \\
Formula III & 0.391 & 0.957 & & 0.521 & 1.173 \\
\hline
\end{tabular}

Table 4: Average hardness of papaya and bay leaf tablets

\begin{tabular}{lll}
\hline Results & Average hardness (kp) & Hardness range (kp) \\
\hline Formula I & 5.465 & $4.5-6.5$ \\
Formula II & 6.945 & $5.6-8.2$ \\
Formula III & 5.810 & $4.7-6.8$ \\
\hline
\end{tabular}

Table 5: Average of tablets' friability

\begin{tabular}{ll}
\hline Results & Average friability (\%) \\
\hline Formula I & 0.34 \\
Formula II & 0.27 \\
Formula III & 0.53 \\
\hline
\end{tabular}

Table 6: Average of tablets' disintegration time

\begin{tabular}{ll}
\hline Results & Disintegration time \\
\hline Formula I & 6 minutes 8 seconds \\
Formula II & 11 minutes 35 seconds \\
Formula III & 13 minutes 97 seconds \\
\hline
\end{tabular}

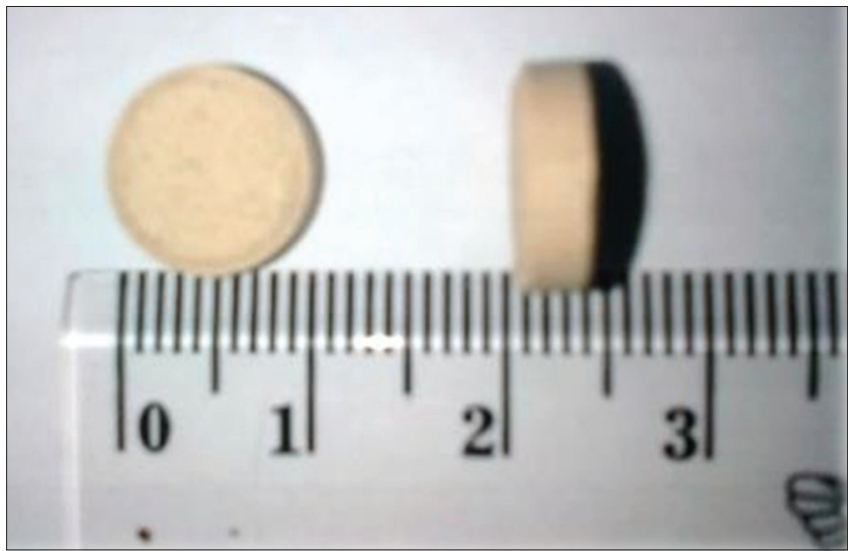

Fig. 5: Tablets formed from the combination of dry papaya and bay leaf extracts

pharmacopoeia, which determined that the disintegration time of a good tablet should be $<15$ minutes [15]. The disintegration of the tablets was influenced by the concentration of the binder. Formula III has the longest disintegration time. The tablets' disintegration time was possibly influenced by the tablets' level of super disintegrants and fillers in the tablets' formulation. The super disintegrant Ac-Di-Sol used in the tablets has an intense mechanism of destruction although it can be compared to other types of disintegrants at low concentrations. The use of avicel as the filler in the tablet formulas also affected the disintegration time of tablets. According to the literature, the substance that can improve the flow of powder will accelerate the dissolution of the tablet obtained, and hydrophilic derivative compounds such as avicel are not soluble in water; thus, avicel can absorb water into the tablet and facilitate the release and dissolution of the tablet and its content [16].

\section{Total flavonoid content in the tablets}

Quantitative analysis was conducted to determine the flavonoid content in the tablets. The analysis was done using UV-Vis spectrophotometry methods because other excipients such as the fillers in the tablets do not absorb UV light, and thus, did not interfere with the measurement [17].

The average total flavonoid content of the tablets obtained from Formula I, Formula II, and Formula III were $4.157 \%, 4.217 \%$, and $3.756 \%$, respectively. The level of flavonoid content in the tablets was decreased by $13.5 \%$ on average. This reduction in flavonoid content may occur due to the damage of certain flavonoid compounds during the granulation and tableting processes as well as the effect of the moisture level of materials in the formula.

\section{CONCLUSION}

It can be concluded that PVP K-30 concentration can be used as a binder to formulate dry papaya and bay leaf extracts into high-quality and ready-to-consume tablets. The concentration of PVP-K30 was $1 \%$ (Formula I), 2\% (Formula II), and 3\% (Formula III). The total flavonoid content found in the papaya leaf extract was $1.562 \%$, the bay leaf extract was $2.240 \%$ and tablets Formula I, Formula II, and Formula 2 were $4.157 \%, 4.217 \%$, and $3.756 \%$, respectively.

\section{REFERENCES}

1. Fakeye TO, Oladipupo T, Showande O, Ogunremi Y. Effect of coadministration of extract of Carica papaya Linn (family Cariaceae) on activity of two oral hypoglycemic agents. Nigeria: Department of Clinical Pharmacy and Pharmacy Administration, University of Ibadan; 2007.

2. Taufiqurrohman T. Indonesian bay leaves as antidiabetic for Type 2 diabetes mellitus. J Majority 2015;4:101-8.

3. Musyrifah SB, Utaminingsih B, Laili FN. Pastiles Daun Salam (Eugenia polyantha W). Yogyakarta: Universitas Gajah Mada; 2012. 
4. Anwar E. Excipients in Pharmaceutical. Jakarta: Dian Rakyat; 2012.

5. Siregar CJ, Wikarsa S. Pharmaceutical Technology in Tablet. Jakarta: Penerbit Buku Kedokteran; 2010.

6. Rowe RC, Sheskey J, Quinn ME. Handbook of Pharmaceutical Excipients. $6^{\text {th }}$ ed. London, Chicago: Pharmaceutical Press and American Pharmacists Association; 2009. p. 134-728.

7. Khar RK, Vyas SP, Ahmad FJ, Jain GK. Lachman/Lieberman's the Theory and Practice of Industrial Pharmacy. $4^{\text {th }}$ ed. India: CBS Publishers and Distribution; 2013.

8. Ministry of Health Republic of Indonesia. Parameters Common Standard Medicinal Plant Extracts. Jakarta: Directorate of Food and Drug Administration; 2000.

9. Kementerian Kesehatan Republik Indonesia. Materia Medika Indonesia. $5^{\text {th }}$ ed. Jakarta: Materia Medika Indonesia; 1995

10. Hanani E. Analysis of Phytochemistry. Jakarta: Penerbit Buku Kedokteran; 2015.
11. Kementerian Kesehatan Republik Indonesia. Suplemen I Farmakope Herbal Indonesia. Jakarta: Direktorat Makanan dan Obat; 2010.

12. Kementerian Kesehatan Republik Indonesia. Farmakope Indonesia. $5^{\text {th }}$ ed. Jakarta: Kementerian Kesehatan; 2014.

13. Parrot EZ. Pharmaceutical Technology-Fundamental Pharmaceutics. The United Stated of America: Burgess Publishing Company; 1971

14. Lachman H, Lieberman J. In: Suyatmi S, Kawira J, Aisyah L, editors. (Teori dan Praktek Farmasi Industri). Teory and Practice of Industrial Pharmacy. Jakarta: UI Press; 2007.

15. Ministry of Health in Republic of Indonesia. Farmakope Indonesia. $5^{\text {th }}$ ed. Jakarta: Indonesian Ministry of Health; 2014

16. Devissaguet JA. In: Soeratri W, editor. Farmasi 2 Biofarmasi. Surabaya: Airlangga University Press; 1993.

17. Watson DG. In: Syarief WR, editor. Analysis of Pharmaceutical. Jakarta: EGC; 2009 